\title{
Selected elements of the Neighborly Exchange of Energy - profitability evaluation of the functional model
}

ABSTRACT: The inevitability and successive implementation of the elements of the European Union (EU) energy policy and the freedom of achieving the goals left in this regard for the member states should translate into actions taking the specificity of local markets into account, in order to carry out liberalization processes in a harmonious manner. In 2016, the European Commission published a package of guidance documents "Clean Energy for All Europeans" in the perspective of 2030, also known as the Winter Package. The recommendations contained in some of the documents assume the continuation of integration of markets in the national and regional dimension, setting ambitious targets in the field of decarbonization, the increase of energy efficiency and the increase of Renewable Energy Sources (RES) share in the energy balance of EU countries. The short time to carry out a thorough reconstruction of the energy-generating sector forces to seek solutions that are in line with the European Community recommendations and, at the same time, do not constitute an excessive burden for the national economy and legal order. One of the activities is to use the potential of micro-networks of local communities striving for energy independence based on their own energy sources and to create regulations enabling the neighborly exchange of energy. This mechanism works in the form of pilot projects in many locations around the world (Sonnen Group; Power

$\triangle$ Corresponding Author: Joanna Wróbel; e-mail: joanna.wrobel@pse.pl

1 PSE Innowacje Sp. z o.o., Poland; e-mail: joanna.wrobel@pse.pl

2 PSE Innowacje Sp. z o.o., Poland; ORCID iD: 0000-0002-9639-3616; e-mail: Maciej.soltysik@pse.pl

3 E-mail: rogusradomir@gmail.com

2019. The Author(s). This is an open-access article distributed under the terms of the Creative Commons Attribution-ShareAlike International License (CC BY-SA 4.0, http://creativecommons.org/licenses/by-sa/4.0/), which permits use, distribution, and reproduction in any medium, provided that the Article is properly cited. 
Ledger). The paper presents the concept of functional and analytical assumptions for an exemplary structure of neighboring prosumers along with the presentation of simulation results based on real generation and consumption profiles and the presentation of investment profitability indicators for the proposed functional model.

KEYWORDS: neighborly exchange of energy, prosumer, renewable energy

\section{Introduction}

The amendment to the Polish Act on RES introduces the so-called prosumer package, resulting from the work of the Inter-ministerial Team for Facilitating Investment in Prosumer Renewable Energy. The changes included in the package are the implementation of the assumptions of the Energy Plus program, whose main goal is to accelerate the development of prosumer energy. A key provision broadens the definition of prosumer as: "a final customer generating electric energy only from renewable energy sources for his own needs in a micro-installation, that can store or sell that electricity to the obliged or another seller, provided that in the case he is not the electricity consumer in the household, this is not the subject of his prevailing economic activity" (Polish Parliament 2019). The new formulation of this definition means that entrepreneurs who produce electricity from micro-installations (i.e. up to a maximum power of $50 \mathrm{~kW}$ ), for whom electric energy generation is not the main area of activity, will be able to be prosumers of renewable energy. The same applies to energy cooperatives that can be created in villages and in urban-rural communes. Additionally, new provisions regarding the location of micro-installations seem to be significant, which enable the installation of photovoltaic panels wherever this is not ruled out by the local spatial development plan and eliminate the obligation to prepare a construction project for micro-installations up to $6.5 \mathrm{~kW}$ (Cire.pl 2019). All solutions implemented within the prosumer package aim to accelerate the expansion of civic energy as part of the current guidelines of the "Clean Energy for all Europeans" (Directive... 2018) package in the scope of increasing the share of RES in the energy mix and reducing $\mathrm{CO}_{2}$ emissions and the global trend of development of PV sources (Mirowski and Sornek 2015).

On the basis of such a structured legal framework, it becomes particularly important to build market mechanisms that further increase the attractiveness of the prosumer segment and are part of the recommendations of the European Commission. One of such activities may be the Neighborly Exchange of Energy (NEE), which is an innovative solution in Poland, responding to the ever-growing level and changing profile of energy demand, which forces the search for optimal methods of satisfying it.

The NEE model fits into the promotion of decentralized and dispersed RES development, and thanks to a sustainable functional model it increases investment profitability and has a real impact on the formation and growth of local energy communities. An example of using the 
energy potential located in the urban space can be the creation of an energy cooperative within a multi-family residential building and the formation of the NEE within the Internal Power Supply Line (IPSL).

\section{Neighborly Exchange of Energy - functional assumptions}

The functioning of NEE through the sharing of locally produced energy requires the adoption of several fundamental assumptions:

- Undertaking formal and legal actions aimed at establishing an energy cooperative, comprising at least several participants. The functional model is based on the exchange of surpluses of produced energy, therefore, the prosumers should play a key role in this process. The statute of a cooperative, in which all issues describing relations, connections and framework of functioning should be reflected, including both investment and operational activities is necessary and particularly important.

$\downarrow$ The internal low-voltage power line, owned by the residential community that forms the energy cooperative, will be used in order to allow NEE operation. In the functional model of the NEE, energy distribution using IPSL may be unburdened by cost components related to energy supply from the external grid, which significantly affect the profitability of the NEE. The contact point of the internal power line with the network of the Distribution System Operator (DSO), which is also the boundary of balancing, should be metered.

$\checkmark$ The NEE model can operate on the basis of a rebate mechanism, as well as take the possibility of storage of surplus energy and its usage in an internal market exchange into account. The installation of energy storage is not an indispensable element, but it can improve the efficiency of exchange of energy and reduce the consumption from the OSD network. However, energy storage is associated with the need to incur large capital expenditures, which can be an important element limiting such use within the NEE. Energy can be consumed from the local storage unit at no cost, while the energy stored in the DSO network can be consumed based on the rebate mechanism (Act... 2015). Energy consumption from the grid is costless at a level corresponding to 80 or $70 \%$ of the volume previously stored in the distribution network. It is connected with incurring the storage cost of 20 or $30 \%$ of the volume directed to the external grid, respectively for installations with a capacity of up to $10 \mathrm{~kW}$ and in the range of 10-50 kW. Pursuant to the amended regulations, energy cooperatives will incur a cost of $40 \%$ of energy supplied to the external network.

$\checkmark$ The participation of the energy cooperative members in the NEE is strongly linked with the necessity to incur investment outlays, especially in the generation, storage and measuring infrastructure. The financial input may have a different value, which will also determine the generation volume that each of the shareholders - members of the energy cooperative will be able to dispose. Energy generated in a shared PV installation, firstly covers the current 
demand of each NEE member in accordance with its share. Any surplus goes to another NEE member in a direct way, or with the use of a local energy storage. In the situation of full charge in the local storage, the energy is directed into the DSO grid, which acts as a network magazine. In the case of non-generation, the current needs of the entity are covered from the energy accumulated in the local storage, and in the case of discharge, from the DSO network. The illustration of the functional model was presented in Figure 1.

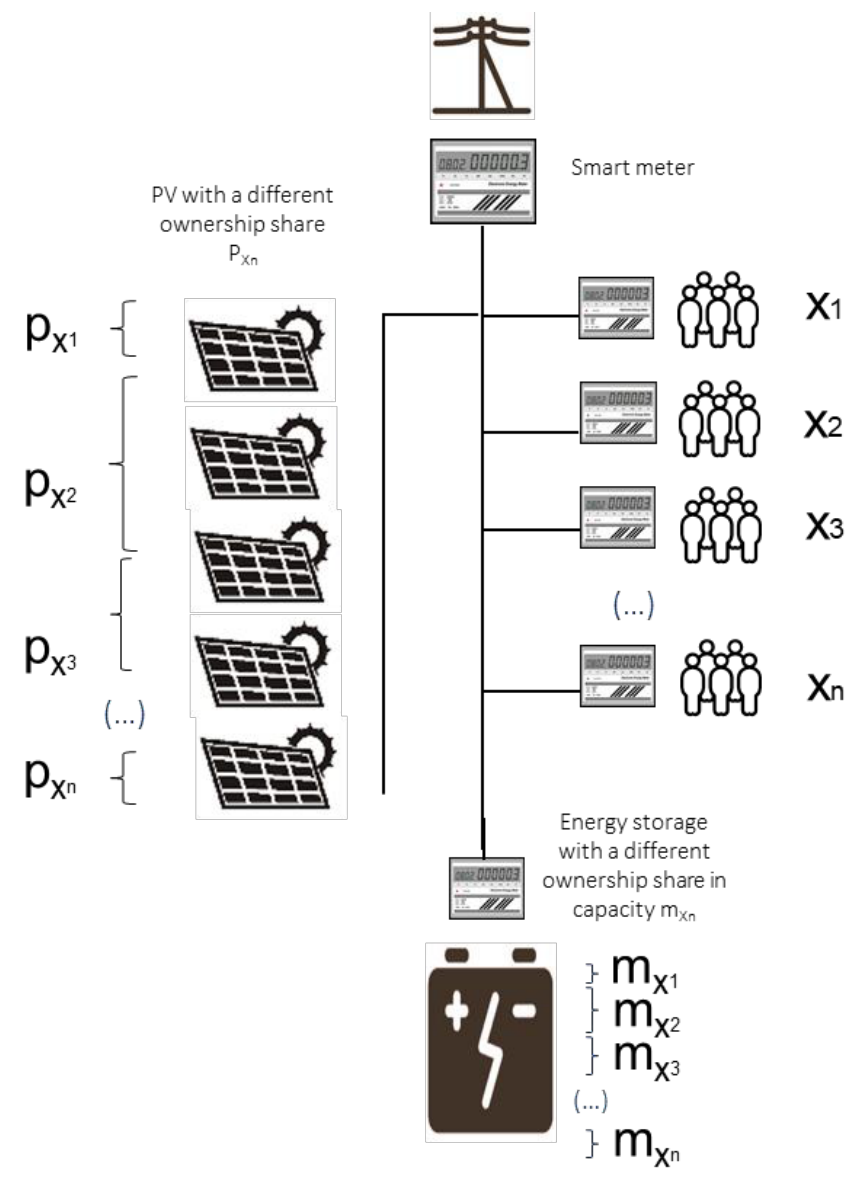

Fig. 1. Structural connections model

Rys. 1. Architektura struktury połączeń 


\section{Neighborly Exchange of Energy - case study}

The simulation analysis carried out by the authors was an attempt to reflect the mechanisms and assumptions in the real environment, within the existing community of residents from multifamily building, where the participation of entities in the exchange of energy is related to participation in investment outlays incurred on the generation and storage infrastructure. The simulation projects the adaptation of the NEE model to the actual generation and consumption profiles. The analyses were carried out for the annual history of daily and hourly data representing five different types of energy consumption and PV generation profiles. In order to demonstrate the benefits of the application of the NEE, the analysis was carried out in two scenarios. Scenario 1 included only the calculation of results in the rebate model, and scenario 2 included the possibility of energy exchange via the storage. Both scenarios provide a full picture of the benefits only when referred to the baseline scenario assuming the purchase of energy entirely under comprehensive agreements. Detailed assumptions of the conducted simulation were defined as follows:

$\checkmark$ The energy cooperative and thus the NEE enclosed all the households in the building. It was assumed that the share of each household in the generation and storage infrastructure will constitute an input variable to the optimization model and will be proportional to the individual amount of consumed energy.

\ The $50 \mathrm{~kW}$ photovoltaic installation was set-up on the rooftop surface area of 372 square meters. The power was adjusted to the presence of shadows on the roof's surface which limit the effective energy output and to the necessity of assuring space for maintenance works.

- A local $54 \mathrm{kWh}$ energy storage was installed in the building, constituting a cascade of four PowerWall 2-type storage units with a capacity of $13.5 \mathrm{kWh}$ each.

$\downarrow$ The real data on the generation of a $1 \mathrm{MW}$ solar farm was used, which were scaled up to $50 \mathrm{~kW}$.

- The actual data on electricity consumption in households was used. In order to reflect the reality, the NEE entities were divided into five types of households that differ in their daily consumption profile and the annual level of energy demand related to their individual specificity: (i) two-generation household with limited night activity $-2+2$ model, assuming the professional activity of one of the adult members at night, (ii) two-generation household with limited afternoon activity $-2+2$ model, assuming the professional activity of one of the adult members in the afternoon, (iii) two-generation household with limited activity in the afternoon $-2+2$ model, assuming the professional activity of one of the adult members in the morning, (iv) a two-person household with an energy-saving consumption profile, (v) single-person household with an energy-saving consumption profile.

- An economic analysis of the mechanism of the exchange of energy was based on the following price levels: (i) PLN 600 /MWh when purchasing the Energy in terms of comprehensive agreement, (ii) PLN 540 /MWh when applying the direct NEE model, as well as in the scenario with the energy storage installation. 
$\checkmark$ The objective of the optimization process is to minimize the costs of energy purchase by all members of the cooperative in a hybrid exchange of energy that combines its transfer with the participation of the distribution network and neighborly exchange, where the energy is transferred through the local storage unit. The optimization objective is accomplished by: (i) configuration of households' shares (taking the level and profile of their energy demand into account) in the generation and storage infrastructure for which the total costs of energy exchange are minimized, (ii) energy flows within the NEE, taking the local storage and the DSO network, in which the energy of the cooperative's participants is stored, into account.

As part of the analyses, daily and hourly simulations were conducted for each of the NEE's households:

$\checkmark$ Energy flows on the path: (i) PV source - consumer, (ii) PV source - DSO network - consumer, (iii) PV source - energy storage (NEE) - consumer.

$\checkmark$ Analysis of the costs of electricity purchase and income from its replacement in the NEE model.

Aggregated results of the simulation were presented in Figures 2 and 3.
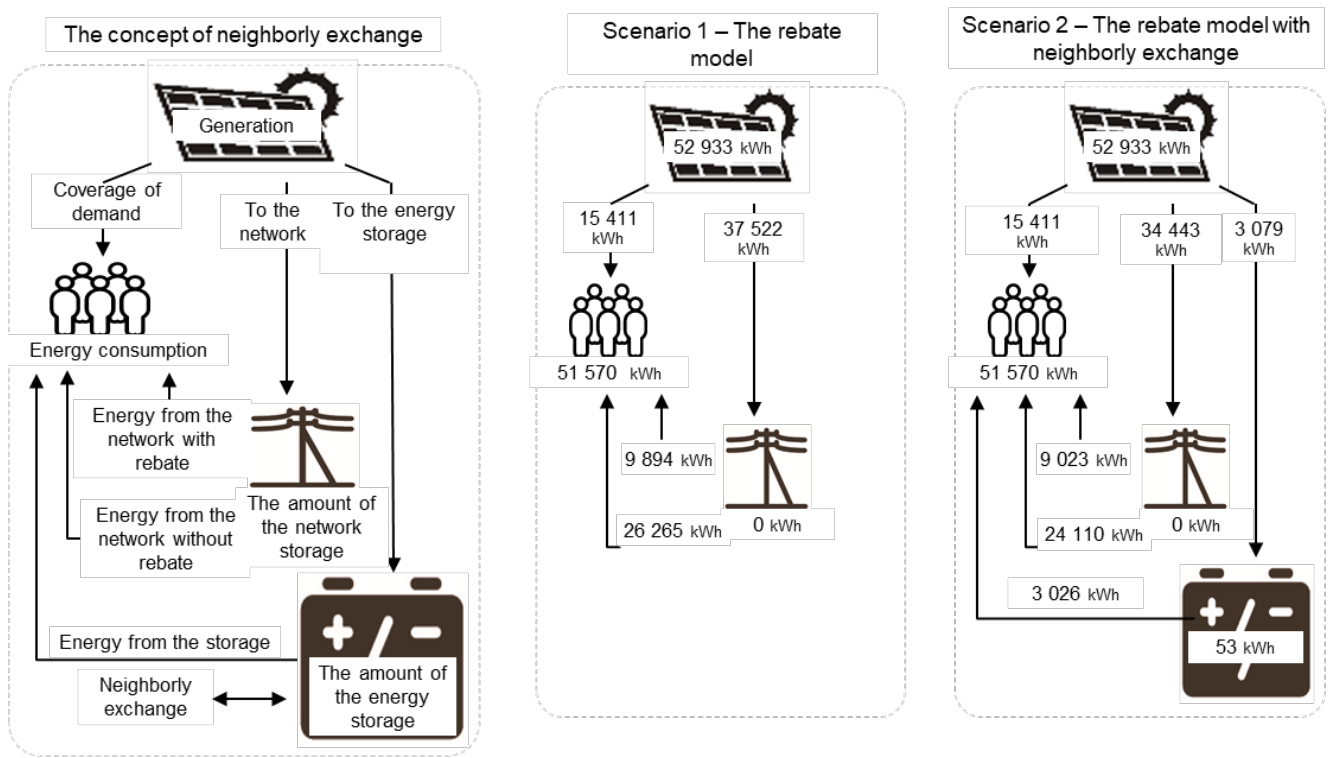

Fig. 2. Energy flows in the analyzed scenarios

Rys. 2. Przepływy energii analizowanego scenariusza

Based on the analyses carried out, the following conclusions can be drawn:

- The level of electricity demand of 30 households participating in the NEE amounted to $51570 \mathrm{kWh} /$ year, and the generation level from the shared PV source amounted to $52933 \mathrm{kWh} /$ year (generation efficiency approx. 12.1\%). Electric energy consumption was 


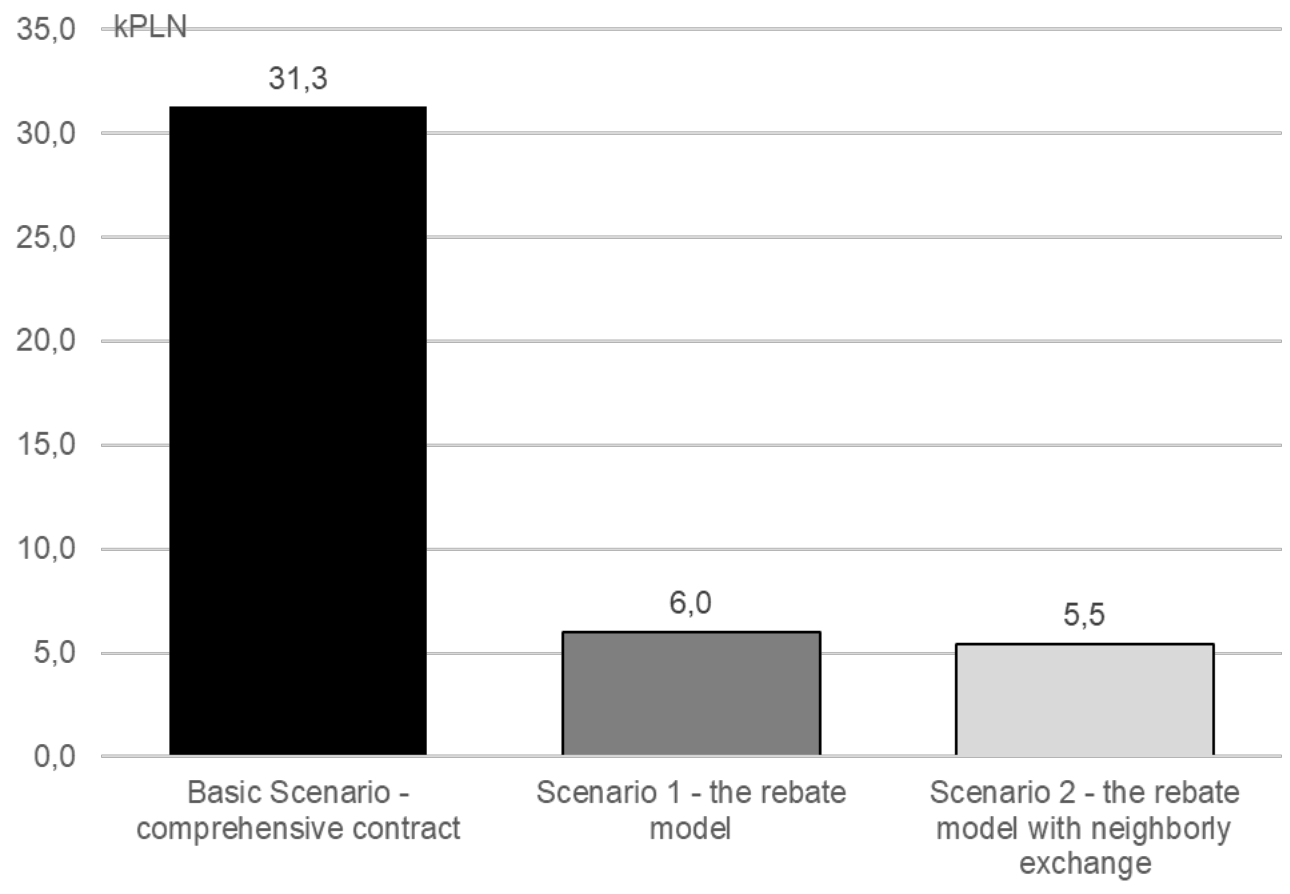

Fig. 3. Annual costs of energy purchase in distinction of individual scenarios

Rys. 3. Roczne koszty zakupu energii w podziale na poszczególne scenariusze

covered from the current local generation (at the same moment of time) in the dimension of $15,411 \mathrm{kWh} /$ year, which constituted approx. $29.9 \%$ of the total demand.

$\checkmark$ Under scenario 1, the remaining amount of energy - 36,159 $\mathrm{kWh} /$ year - necessary to cover the demand was supplied from the DSO distribution network, with $26,265 \mathrm{kWh} /$ year consumed in terms of rebate model, which accounted for $70 \%$ of the volume generated in the PV source and directed to the DSO network $(37,522 \mathrm{kWh} /$ year). As part of the exchange of energy generated from own generation with the DSO network, 11,258 kWh was lost.

- Under scenario 2, the remaining amount of energy - 36,159 kWh/year - necessary to cover the demand was supplied from the DSO distribution network, with $24,110 \mathrm{kWh} /$ year consumed in terms of rebate model, which accounted for $70 \%$ of the volume generated in the PV source and directed to DSO networks $(34,443 \mathrm{kWh} /$ year). As part of the exchange of energy generated from own generation with the DSO network, 10,333 $\mathrm{kWh}$ was lost. Thanks to the NEE coupled with energy storage, additional $3079 \mathrm{kWh} /$ year of energy was utilized from the local generation.

$\checkmark$ It is worth emphasizing that the reduction of energy purchase costs was observed for all members of the energy cooperative. Applying the rebate-only scenario, approximately $80 \%$ cost reduction was obtained from PLN $31.3 \mathrm{k} /$ year to PLN $6.0 \mathrm{k} /$ year. Implementation of the model with the NEE additionally reduces the total costs by about $10 \%$ compared to the re- 
sults from the rebate-only model, and also enables participants to achieve individual financial goals and earn revenues.

The obtained results unambiguously indicate that the realization of both scenarios affects the reduction of energy purchase costs, however, from the perspective of the investment assessment, it is necessary to calculate the profitability indices of the NEE model. For this purpose, an analysis of the basic indicators: NPV, IRR, BEP was performed. The analysis was preceded by the following assumptions:

$\downarrow$ Investment costs (CAPEX) include the following components: (i) the cost of generation infrastructure with assembly PLN 160,000 (3 $200 \mathrm{PLN} / \mathrm{kW}$ ), (ii) the cost of adapting the measurement and settlement equipment PLN 15,000 and optionally (iii) the cost of energy storage PLN 95,200 (only for scenario 2).

$\checkmark$ The operating costs include the following components: (i) the cost of servicing and maintenance of the installation - PLN 650 /year, (ii) the cost of repayment of principal and interest installments on the contracted credit depends on the scenario adopted.

$\checkmark$ It was assumed that the financing of investment will be implemented in one of four variants:

(i) loan at $30 \%$ of CAPEX and non-repayable subsidy of $30 \%$ of CAPEX, (ii) loan at $0 \%$ of CAPEX and non-repayable subsidy of $0 \%$ of CAPEX - financing from own funds, (iii) a loan at the level of $80 \%$ of the CAPEX value and a non-repayable subsidy of $30 \%$ of the CAPEX value, (iv) a loan of $80 \%$ of the CAPEX value and a non-repayable subsidy of $0 \%$ of the CAPEX value.

$\checkmark$ The following loan parameters were adopted: (i) loan term - 15 years, (ii) annual interest rate $-7 \%$, (iii) inflation level $2.5 \%$ YOY, (iv) risk-free rate $3.5 \%$, (v) $3 \%$ risk premium.

$\checkmark$ The following technical and market parameters were adopted: (i) loss of generation efficiency $0.7 \%$ /year, (ii) base price of electric energy and its delivery in the price lists of sellers PLN 600 /MWh, (iii) scenario of varying increment of electric energy prices in seller's price lists: $3 \%, 5 \%, 7 \%, 9 \%$ YOY, (iv) the investment period of 25 years.

The results of the analysis showing BEP and IRR indicators are shown in Figure 4.

The obtained results allow to conclude that the break-even points (BEP) depend on the price growth scenario in the market, between 5-6 years for scenario 1 and 8-10 years for scenario 2 (incl. energy storage). Both the most beneficial results are obtained for the scenario with both loan and a non-repayable subsidy at 30\% level. In the case of financing investments with a loan of $80 \%$ without obtaining a subsidy, the payback periods are expanded for both scenarios to the following ranges: 9-14 years and 14-24 years. It should be emphasized at this point that under scenario 2 , the functioning of the energy storage is characterized by specific and limited lifetime of the device, depending, inter alia, on number of charge-discharge cycles. In relation the intensity of use of the energy storage, it should be assumed that its replacement will take place between 3-5 years after installation, i.e. before the payback period of this investment for each of the analyzed scenarios. This makes the energy storage an unprofitable investment. This is additionally confirmed by the results of the internal rate of return (IRR) calculations, which at the end of the 25 year investment period for scenario 2 varies between 7-14\%. An supplementary picture of investment profitability 

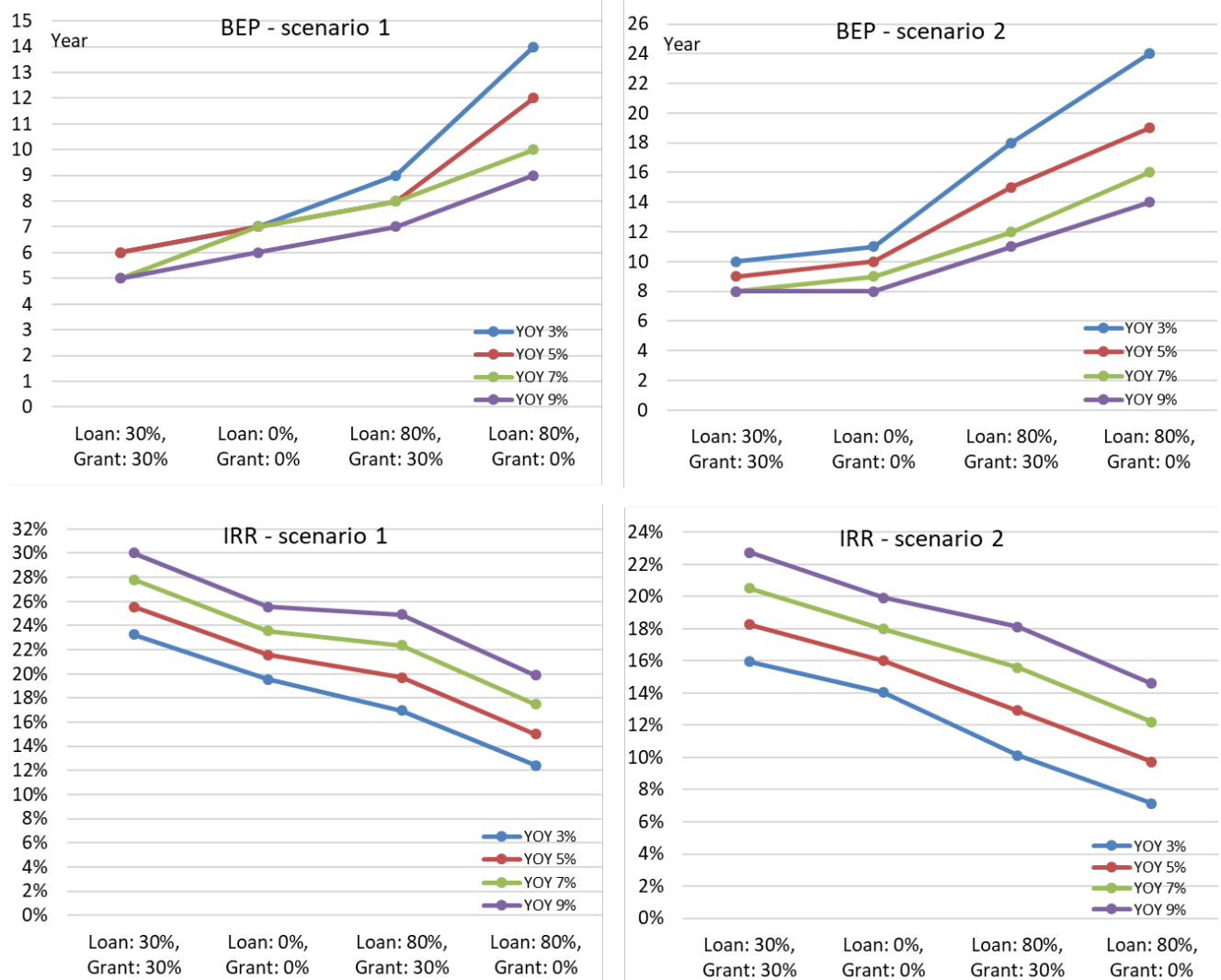

Fig. 4. BEP and IRR results for the considered set of scenarios

Rys. 4. Wskaźniki BEP i IRR rozważanych scenariuszy

is given by the assessment of the net present value (NPV) illustrated for individual years of the investment return period in Figure 5.

The NPV analysis indicates that the most significant financial effect is possible to achieve for scenario 1 (excluding energy storage). Depending on the assumed growth rate of electricity prices, the discounted value of the indicator for the 25-year analysis period varies between PLN $148 \mathrm{k}(3 \%$ YOY) - PLN $720 \mathrm{k}$ (9\% YOY), respectively for the loan $80 \%$ \& subsidy $0 \%$ scenario and both loan $0 \% \&$ subsidy $0 \%$ and loan $30 \%$ and subsidy $30 \%$ scenarios. In the case of scenario 2 (including energy storage) for analogous lending scenarios and the dynamics of market prices, the NPV reaches the value between PLN $23 \mathrm{k}$ and PLN $715 \mathrm{k}$. 

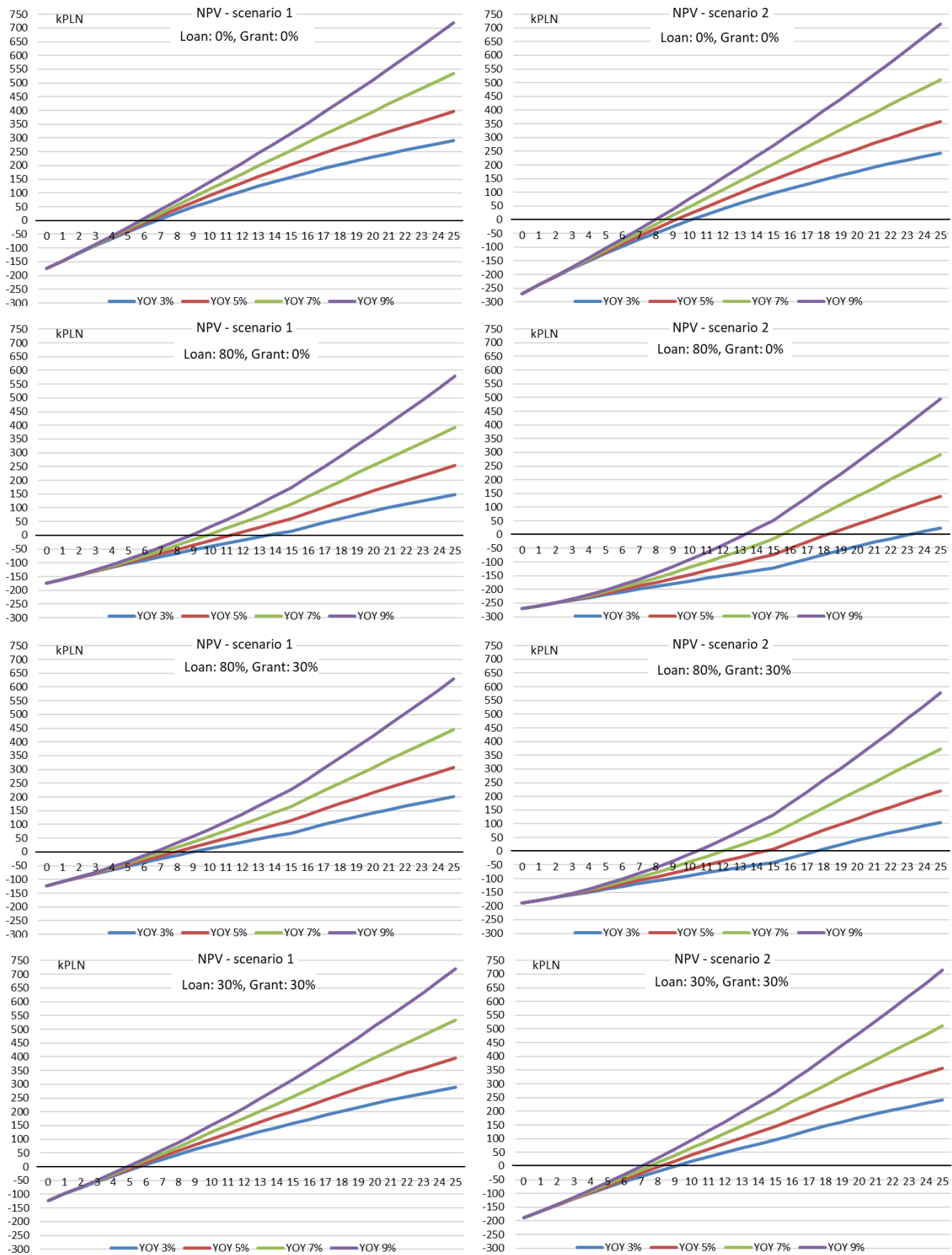

Fig. 5. NPV results for the considered set of scenarios

Rys. 5. Wskaźnik NPV rozważanych scenariuszy 


\section{Conclusions}

The paper shows that it is possible to design functioning and settlement mechanisms that enable NEE within multi-family residential buildings, including a prosumer model. The implementation of assumptions in an authentic building brings the vision of using the potential of urban housing structures in realization of a distributed energy industry based on renewable sources, supporting the country's efforts to achieve the objectives in this matter. The provision of prosumer infrastructure with a common energy storage provides the opportunity to share locally generated energy, increases the energy self-sufficiency and the independence of NEE and limits the amount of energy lost in the rebate model for energy exchange with the DSO network (Sołtysik and Wróbel 2019). Unfortunately, the investment profitability analysis indicates that equipping the prosumer energy installation with energy storage at the current cost does not have economic justification. The investment return period and the cumulative financial effect obtained do not cover investment expenditures. In the opinion of the authors, this conclusion does not negate the validity of the implementation of the NEE model, but only forces the modification of the algorithmic and optimization layer for effective management of energy flows NEE should therefore be implemented as part of scenario 1, using the so-called smart contracts or, ultimately, in scenario 2, but using other, less expensive and more efficient technologies.

\section{Literature}

Act... 2015. The Act of 20 February 2015 on renewable energy sources (Journal of Laws of 2015, item 478).

Cire.pl 2019. Commentary by E. Milewicz. [Online] https://www.cire.pl/item,183847,1,5,12,0,335964,0,emilewicz-tzw-pakiet-prosumencki-to-jedna-z-drog-do-zmniejszenia-emisyjnosci-naszej-energetyki. html\#komentarz [Accessed: 2019-07-29].

Directive... 2018. Directive (EU) 2018/2001 of the european parliament and of the council of 11 December 2018 on the promotion of the use of energy from renewable sources. Official Journal of the European Union 21.12.2018.

MirowsKi, T. and SoRneK, K. 2015. Potential of prosumer power engineering in Poland by example of micro PV installations in private construction (Potencjat energetyki prosumenckiej w Polsce na przykladzie mikroinstalacji fotowoltaicznych $w$ budownictwie indywidualnym). Polityka Energetyczna Energy Policy Journal Vol. 18, Iss. 2 (in Polish).

Polish Parliament 2019. Draft act amending the act on renewable energy sources and some other acts [Online] http://orka.sejm.gov.pl/Druki8ka.nsf/Projekty/8-020-1370-2019/\$file/8-020-1370-2019.pdf [Accessed: 2019-07-29] (in Polish).

Power Ledger. Current Projects. [Online] https://www.powerledger.io/project/bangkok-thailand [Accessed: 2019-07-29]. 
SOŁTYSIK, M. and WRÓBEL, J. 2019. Assessment of chosen elements of prosumer's support mechanism (Ocena wybranych elementów mechanizmu wsparcia prosumentów). Zeszyty Naukowe Wydziału Elektrotechniki i Automatyki Politechniki Gdańskiej No 63 (in Polish).

Sonnen Group. Sonnen community. [Online] https://sonnengroup.com/sonnencommunity [Accessed: 2019-07-29].

\section{Wybrane elementy sąsiedzkiej wymiany energii - ocena rentowności modelu funkcjonalnego}

\section{Streszczenie}

Nieuchronność i sukcesywność wdrażania elementów wspólnotowej polityki energetycznej oraz pozostawiona w tym względzie krajom członkowskim swoboda realizacji celów powinna przekładać się na działania uwzględniające specyfikę lokalnych rynków, tak aby w możliwie harmonijny sposób przeprowadzić procesy liberalizacyjne. W 2016 roku został opublikowany przez Komisję Europejską pakiet dokumentów kierunkowych „Czysta energia dla wszystkich Europejczyków” w perspektywie do 2030 roku, zwany także Pakietem Zimowym. Rekomendacje zawarte w części dokumentów zakładają kontynuację integracji rynków w wymiarze krajowym i regionalnym, stawiając ambitne cele w zakresie dekarbonizacji, wzrostu efektywności energetycznej i wzrostu udziału OZE w bilansie energetycznym krajów UE. Krótki czas na przeprowadzenie gruntownej przebudowy sektora wytwórczego zmusza do poszukiwania rozwiązań zbieżnych z zaleceniami wspólnotowymi i jednocześnie niestanowiącymi nadmiernego ciężaru dla krajowej gospodarki i ładu prawnego. Jednym z działań jest wykorzystanie potencjału mikrosieci lokalnych społeczności dążących do niezależności energetycznej na podstawie własnych źródeł energii oraz utworzenie regulacji umożliwiających wymianę sąsiedzką energii. Mechanizm ten funkcjonuje w postaci projektów pilotażowych w wielu lokalizacjach na całym świecie. W artykule przedstawiona została koncepcja założeń funkcjonalnych i analitycznych dla przykładowej prosumenckiej struktury sąsiedzkiej wraz z prezentacją wyników symulacji bazujących na rzeczywistych profilach odbiorczo-wytwórczych i prezentacją wskaźników oceny rentowności inwestycyjnej dla zaproponowanego modelu funkcjonalnego.

SŁowA KLUCZOWE: sąsiedzka wymiana energii, prosument, energia odnawialna 